\title{
Silenced Myeloblastosis Protein Suppresses Oral Tongue Squamous Cell Carcinoma via the microRNA-I30a/Cylindromatosis Axis [Retraction]
}

Yang R, Shui Y, Hu S, Zhang K, Wang Y, Peng Y. Cancer Manag Res. 2020;12:6935-6946.

At the authors request, the Editor and Publisher of Cancer Management and Research wish to retract the published paper. Following publication, the authors learned that the OTSCC cell lines described in the article had not been isolated from patient tissue samples but had in fact been cultured for several generations in a public lab prior to being used in the study. Thus, the authors have determined the study does not reliably indicate the results of patients with the type of cancer classification described, and the conclusions of the study are invalid.

Our decision-making was informed by our policy on publishing ethics and integrity and the COPE guidelines on retraction.

The retracted article will remain online to maintain the scholarly record, but it will be digitally watermarked on each page as "Retracted".

\section{Publish your work in this journal}

Cancer Management and Research is an international, peer-reviewed open access journal focusing on cancer research and the optimal use of preventative and integrated treatment interventions to achieve improved outcomes, enhanced survival and quality of life for the cancer patient.
The manuscript management system is completely online and includes a very quick and fair peer-review system, which is all easy to use. Visit http://www.dovepress.com/testimonials.php to read real quotes from published authors. 